\title{
6 \\ Innovation and its growth effects in China
}

\author{
Sizhong Sun
}

\section{Introduction}

Innovation plays a central role in a country's economic development. Successful innovations create new ideas that help society progress. For a business, a successful innovation is likely to boost its competitive advantage, by reducing the marginal cost of production via process innovation, for example, or by increasing demand for its products via product innovation. Innovation can facilitate resource allocation ${ }^{1}$ and is one of the drivers of sustainable growth. Policymakers frequently employ a number of measures, such as subsidies or tax credits, to encourage innovation.

One can view innovation as a production process-namely, using a set of inputs (for example, research and development) to produce a set of outputs (for example, new products). As such, innovation has both an input perspective, such as research and development $(\mathrm{R} \& \mathrm{D})$ expenditure and $\mathrm{R} \& \mathrm{D}$ researchers, and an output perspective, including patents. The Organisation for Economic Co-operation and Development (OECD 2018) defines four types of innovation in the Oslo Manual-product, process, marketing and organisational innovation-which are classifications more concerned with the output perspective.

Owing to the importance of innovation, researchers have investigated it from various dimensions, one of which is the determinants of innovative activities. For R\&Dthe input perspective of innovation-previous studies exploring its determinants include Belderbos et al. (2013) in Europe, Japan and the United States; Hammadou

1 For example, Acemoglu et al. (2011) find that patents—an output of innovative activities—improve resource allocation via encouraging experimentation and knowledge transfer. 
et al. (2014) in 14 European countries; Okamuro et al. (2011) in Japan; López (2008) in Spain; Chun and Mun (2012) in South Korea; and Kastl et al. (2013) in Italy.

From the output perspective, patents are extensively examined in the existing literature. To name a few, Fischer et al. (1994) studied firms' patent behaviour in the Austrian manufacturing sector, while Nicholas (2011) studied patenting behaviour in the United States during the 1920s. Gedik (2012) and Aldieri (2011) utilised patent citations to capture knowledge diffusion in Australia and the United States, respectively. Buesa et al. (2010) explored the determinants of regional innovation in Europe, where they treated $R \& D$ as the input and patents as the output of a knowledge production function. Chan (2010) studied the international patent application decisions of nine agricultural biotechnology firms from 1990 to 2000, while Figueroa and Serrano (2013) investigated the determinants of patent sale and acquisition decisions by small and large firms.

Compared with the studies of $R \& D$ and patents, there is less research exploring product, process, marketing and organisational innovation. For some examples, however, Gorodnichenko and Schnitzer (2013) investigated how financial constraints influenced a firm's innovation activities, including product innovation, in Europe in 2002 and 2005, where they found a negative impact from financial constraints on domestically owned firms' ability to innovate. The relative lack of studies on these four types of innovation, despite their clear conceptualisation, is possibly due to lack of data, particularly in developing countries.

In this chapter, I explore innovation in China from both the input (R\&D) and the output (patents and the aforementioned four types of innovation) perspectives at both the national and the industry levels. In particular, I focus on the role of innovation in driving economic growth in terms of gross domestic product (GDP) and industrial output.

In so doing, this chapter contributes to the existing literature in two respects. First, it aims to provide an updated and comprehensive picture of innovation in China at an aggregate level, utilising the available industry and national data. An understanding of innovation in China will help readers to better assess China's economic potential in the future. Second, this chapter aims to evaluate the contribution of innovation to economic growth in China. Since the beginning of the reform and opening up four decades ago, the Chinese economy has been growing at impressive speed, and factors such as institutional reform and the release of cheap labour from the agricultural sector have arguably played important roles in this growth. Currently China has attained the status of an advanced developing economy and is now facing the middle-income trap. Some of these factors may no longer be the source of economic growth. For example, with China's potential arrival at its Lewis turning point (for discussions, see, among others, Cai 2010; Garnaut and Huang 2006; 
Minami and Ma 2010), a labour shortage has become a binding constraint on economic growth. In light of such constraints, innovation can be a sustainable source of economic growth for China in the future.

The rest of this chapter is organised into five sections. In section two, I briefly survey existing studies, focusing on those that cover China. Section three presents an update of innovation in China from the dimensions of R\&D, patents, as well as product, process, marketing and organisational innovation. In section four, utilising an autoregressive distributed lag (ARDL) model, I explore the role of R\&D and patents in China's economic growth in both the short and the long terms. In section five, I assess the impacts of innovation on industrial output, utilising industry panel data, and finally, section six will conclude the chapter.

\section{Related literature}

Researchers frequently explore innovation from two perspectives. The first is to examine factors that affect innovation activities-see, for example, Anwar and Sun (2013), Zhou (2014) and Zhou and Song (2016) on the determinants of R\&D in China. The second is to investigate the impacts of innovation activities. My study is related less to the first perspective than to the second. As such, I briefly survey existing studies that explore the second perspective in this section, focusing on those involving China.

$\mathrm{R} \& \mathrm{D}$ is a dimension of innovation that has been extensively explored. Using a rich dataset covering the population of China's large and medium-sized manufacturing enterprises, Jefferson et al. (2006) find that R\&D expenditure promotes firms' product innovation, productivity and profitability. $\mathrm{Li}$ and $\mathrm{Lu}$ (2018) find that R\&D promotes the green-sophistication of Chinese exports. Zhang and Xie (2020) examine the impacts of $R \& D$ investment and product innovation on China's export performance, and find that these innovation activities promote export propensity, but not export intensity. Similarly, Wu et al. (2020) find that innovation activity, measured in terms of $\mathrm{R} \& \mathrm{D}$ expenditure, promotes export-extensive, but not exportintensive, margins. In the mining sector, Rafiq et al. (2016) find that Chinese mining firms with R\&D activities have higher profitability and sales revenues than those without. Similarly, Sun and Anwar (2019) observe that domestic firms in China's iron ore mining industry that conduct $\mathrm{R} \& \mathrm{D}$ are, on average, more productive and have higher sales revenue. Chinese government $\mathrm{R} \& \mathrm{D}$ programs are also found to promote firms' innovation outputs, including the number of patents and revenue from new product sales (Guo et al. 2016).

Hu et al. (2017) find that the correlation between patents and labour productivity has weakened, despite a surge in patent applications in China. The increase in applications does not mean that patent quality, measured in terms of citations, 
is high. Fisch et al. (2017) observe that, compared with the United States, Europe, Japan and South Korea, Chinese patents have lower value in terms of citations, with similar findings made by Boeing and Mueller (2019).

Dai and Cheng (2018) assess the effect of product innovation on firm markup and productivity, using a large sample of Chinese manufacturing firms. They find significantly positive impacts on firm markup and revenue productivity by product innovation, but its influence on adjusted productivity is negative or insignificant. Zhu et al. (2021) link product and process innovation to employment in China, where they find process innovation serves to promote employment, while product innovation dampens employment.

Many studies on innovation activities in China explore the regional dimension. Chen and Guan (2010) utilise a method of data envelopment analysis to measure the efficiency of China's regional innovation systems, finding a low level of efficiency. Similarly, Bai (2013) estimates the regional innovation efficiency in China from 1998 to 2007 using a stochastic frontier approach and finds low innovation efficiency. Fu et al. (2012) investigate the path-dependent evolution of regional innovation systems in Shenzhen and Dongguan.

Fan et al. (2012) assess the regional innovation inequality in China from 1995 to 2006 , finding $R \& D$ to be one of the major drivers of increases in inequality. Huang et al. (2010) find double-threshold effects for regional innovation on the productivity spillovers from foreign direct investment in 29 Chinese provinces between 1985 and 2008. Using a multi-agent-based simulation, Wang et al. (2014) show that policies can promote the process of innovation diffusion, which in turn boosts the economies of less-developed regions, particularly in central China.

$\mathrm{Fu}$ and $\mathrm{Mu}$ (2014) explore the policy choices in the extended national innovation performance framework, while Liu et al. (2011) and Wu (2012) assess the evolution of China's innovation policies. Fan (2014) critically reviews the studies of China's innovation capability, including the development pathway of its national innovation system.

The research in this chapter has three distinct features that distinguish it from these existing studies. First, it covers more types of innovation activities, including R\&D, patent, product, process, marketing and organisational innovation. Second, it analyses China's innovation activities and their growth effects at the industry and national levels. Third, it does not cover the regional dimension of innovation activities. 


\section{Overview of innovation in China}

Over the past few years, innovation in China-in terms of inputs (R\&D) and outputs (for example, patents) — has been on a rising trajectory. Figure 6.1 shows the trend for both $\mathrm{R} \& \mathrm{D}$ expenditure and the number of full-time-equivalent $R \& D$ researchers. The top-left panel of Figure 6.1 suggests that the number of full-time-equivalent $\mathrm{R} \& \mathrm{D}$ researchers has been growing at increasing speed, to reach 4.61 million in 2019. The increasing R\&D personnel will, not surprisingly, contribute to the growth of innovation outputs, which in turn will boost economic growth. The trend for $\mathrm{R} \& \mathrm{D}$ expenditure (as a share of GDP), shown in the top-right panel of Figure 6.1, appears different to that for the number of R\&D researchers. First, it pursued a downward trend before 1997, reaching a low of 0.5 per cent in 1994; second, after 1997, R\&D expenditure began to rise substantially, reaching a peak of 2.2 per cent in 2019. However, its growth rate appears to be declining. From 1989 to 2019 , R\&D expenditure (as a share of GDP) increased more than threefold, from 0.7 per cent in 1989 to 2.2 per cent in 2019. Despite the figure appearing relatively modest (less than 2.2 per cent), the increasingly large size of the Chinese economy (GDP) implies a large volume of R\&D investment.

The accelerating growth rate in the number of $R \& D$ researchers, coupled with the declining growth rate of $R \& D$ expenditure (relative to GDP), suggests an increased share of spending on R\&D personnel. The bottom-left panel of Figure 6.1 shows the association between the number of $R \& D$ researchers and $R \& D$ expenditureappearing to confirm this. We can observe that a 1 per cent increase in $R \& D$ expenditure is associated with a more than 1 per cent increase in the number of $R \& D$ researchers when $R \& D$ expenditure is at a high level. Nevertheless, despite the link between the number of $R \& D$ researchers and $R \& D$ expenditure, their growth rates do not appear to be substantially linked (the bottom-right panel of Figure 6.1).

In Figure 6.2, I examine patent applications made by both residents and nonresidents and associate them with the number of $R \& D$ researchers and expenditure levels. The top-left panel of Figure 6.2 exhibits the time trends of patent applications of residents and non-residents, from which three features emerge. First, patent applications by both residents and non-residents exhibit an increasing trendconsistent with the rise in $R \& D$ expenditure and researcher numbers in Figure 6.1. Second, the number of patent applications before 2000, from residents and nonresidents, is relatively modest and the growth trend is less obvious compared with that of the post- 2000 period-once again, consistent with the pattern of inputs ( $R \& D$ expenditure and researchers). As is observable in Figure 6.1, both R\&D expenditure and the number of researchers grew substantially faster after 2000 than in the preceding period. Third, the number of patent applications made by residents 
has come to dominate that made by non-residents since 2005, with the gap increasing over the years (also see the top-right panel of Figure 6.1). Clearly therefore, residents have come to play an increasingly crucial role in innovation in China.

The association between residents' patent applications and R\&D inputs (expenditure and number of researchers) also differs from that for non-residents. The bottom-left panel of Figure 6.2 plots the number of patent applications against the number of $R \& D$ researchers and displays the corresponding fitting curves. For residents' patent applications, the convex and upward sloping fitting curve suggests a positive correlation with the number of $R \& D$ researchers and that the degree of association becomes higher at higher numbers of researchers. In contrast, despite the similarly positive correlation for non-residents' patent applications, the fitting curve is concave, indicating that a unit increase in the number of $R \& D$ researchers is associated with a smaller increase in the number of non-residents' patent applications. The bottom-right panel of Figure 6.2 presents the associations with $R \& D$ expenditure. For residents' patent applications, we can observe a pattern similar to their association with the number of $R \& D$ researchers. In contrast, the fitting curve of the scatter plot between non-residents' patent applications and R\&D expenditure becomes linear. Therefore, $\mathrm{R} \& \mathrm{D}$ inputs appear to be differentially associated with patent applications by residents and non-residents.

Figure 6.3 provides a snapshot of product, process, organisational and marketing innovation by displaying the distributions of the share of enterprises (above designated size) that engaged in these four types of innovation in two-digit industries in 2018. The dots and horizontal bars in Figure 6.1 represent the median and mean of these shares, respectively. On average, 22.92 per cent of enterprises above designated size conducted product innovation, 26.62 per cent conducted process innovation, 26.91 per cent conducted organisational innovation and 23.4 per cent conducted marketing innovation. Comparing the means with the medians in Figure 6.3, we can observe that they are close to each other in all four distributions, suggesting symmetrical distributions. Comparing the means and medians across the four innovation types, we can see that more firms conducted organisational and process innovation than marketing and product innovation. 

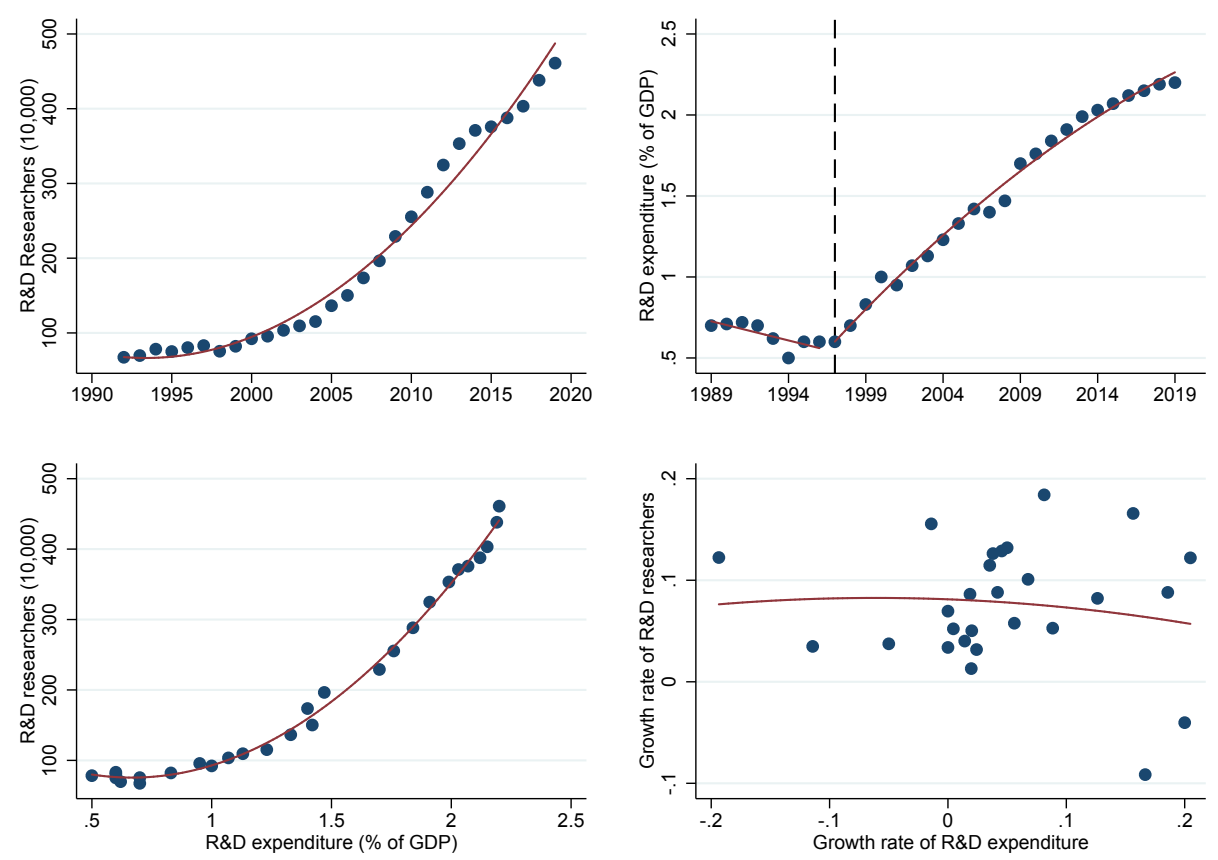

Figure 6.1 R\&D expenditure and number of full-time-equivalent $R \& D$ researchers

Source: NBS (2021).
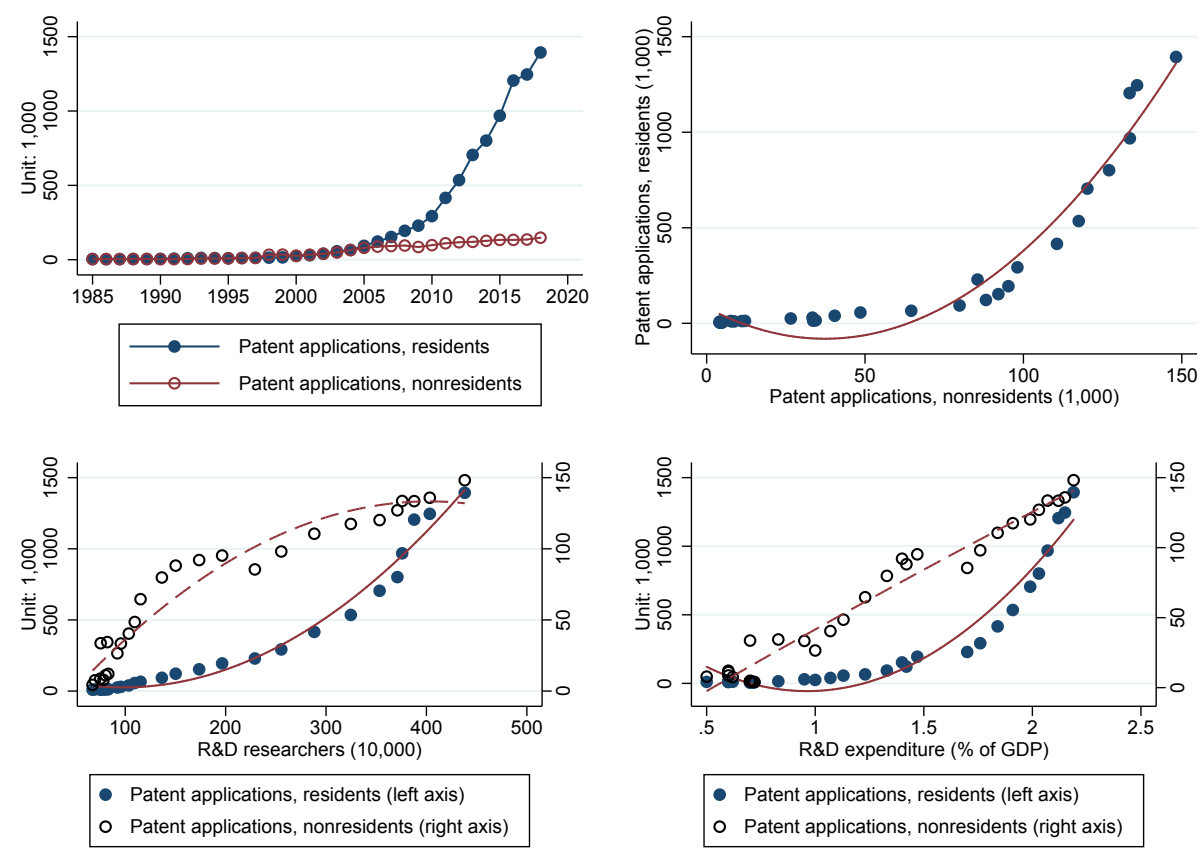

Figure 6.2 Patent applications

Sources: NBS (2021); World Bank (2021). 


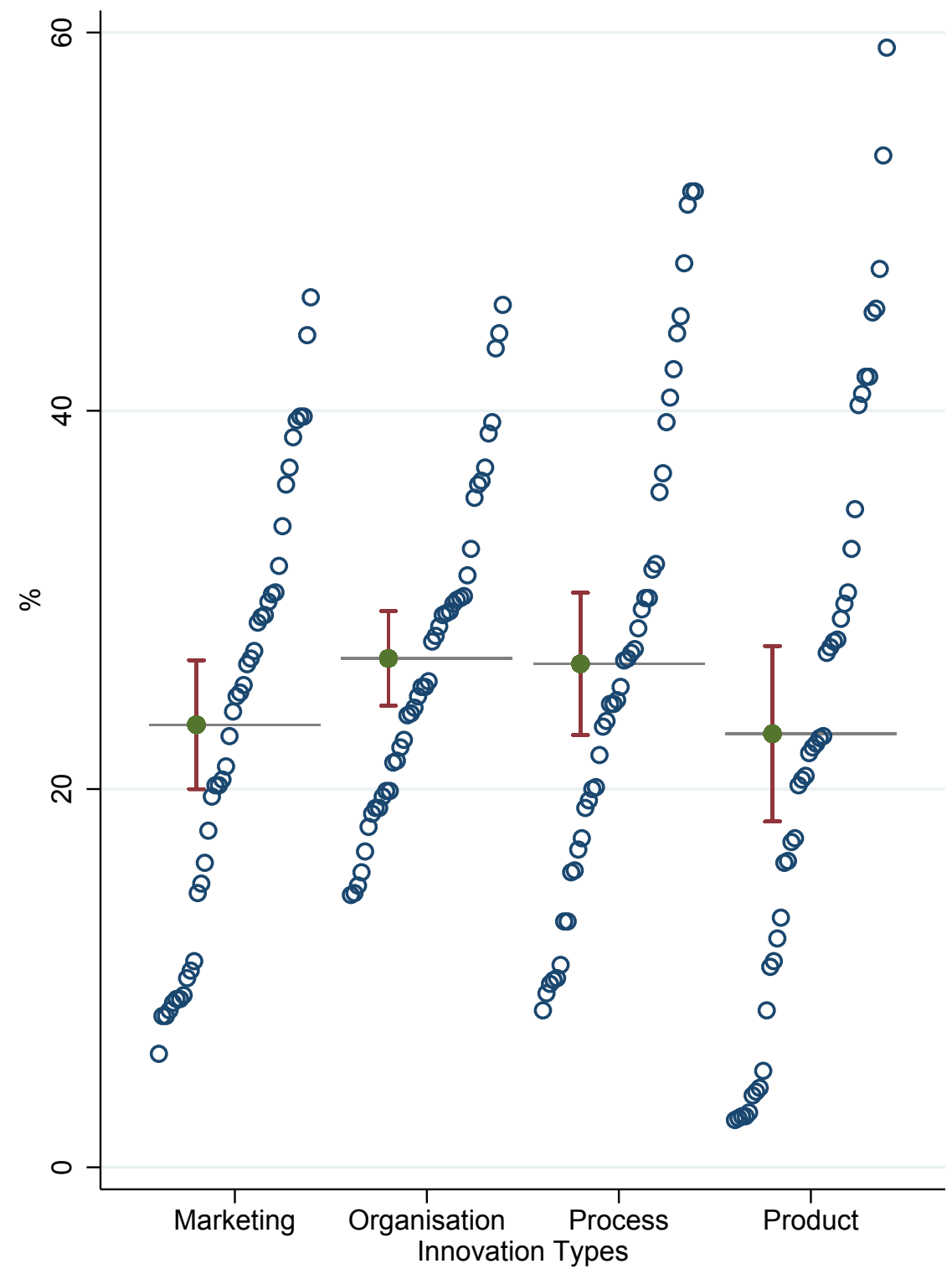

Figure 6.3 Share of enterprises (above designated size) conducting product, process, organisational and marketing innovation, by industry, 2018 (per cent)

Source: NBS (2021).

For product innovation, the instrumentation manufacturing industry has the highest share of enterprises conducting product innovation (59.2 per cent). In contrast, the coal mining and washing industry reports the lowest share of enterprises with product innovation (2.5 per cent). Among enterprises conducting process innovation, the instrumentation manufacturing industry again registers the highest share, with 51.6 per cent, while the mining sector displays the lowest share, with 
the coal mining and washing industry at 9.2 per cent and other mining industries at 8.3 per cent. The instrumentation manufacturing industry continues to also occupy the top position in organisational innovation, registering a share of 45.6 per cent. In contrast, the nonmetallic mining and dressing sector reports the lowest share, of 14.4 per cent. In marketing innovation, the industries with the highest and lowest shares are the pharmaceutical manufacturing industry and the ferrous metal mining and dressing industry, with shares of 46 and 6 per cent, respectively, while the instrumentation manufacturing industry has the second-highest share of enterprises with marketing innovation, at 44 per cent. Generally, the mining sector exhibits lower shares across all four types of innovation when compared with the manufacturing sector.

Owing to data availability, I am able to examine the dynamics of product innovation in terms of the number of new-product projects across industries between 2011 and 2018. Figure 6.4 presents these distributions across the eight years in question. Here we can observe two patterns: first, the average number of new-product projects (the curve with circles in Figure 6.4) exhibits a weak upward trend, which becomes more obvious after 2015, with the median (the bars in the boxes in Figure 6.4) exhibiting a similar pattern; second, the means are substantially higher than the medians in all eight years, due to some industries having large numbers of newproduct projects (the outliers in Figure 6.4).

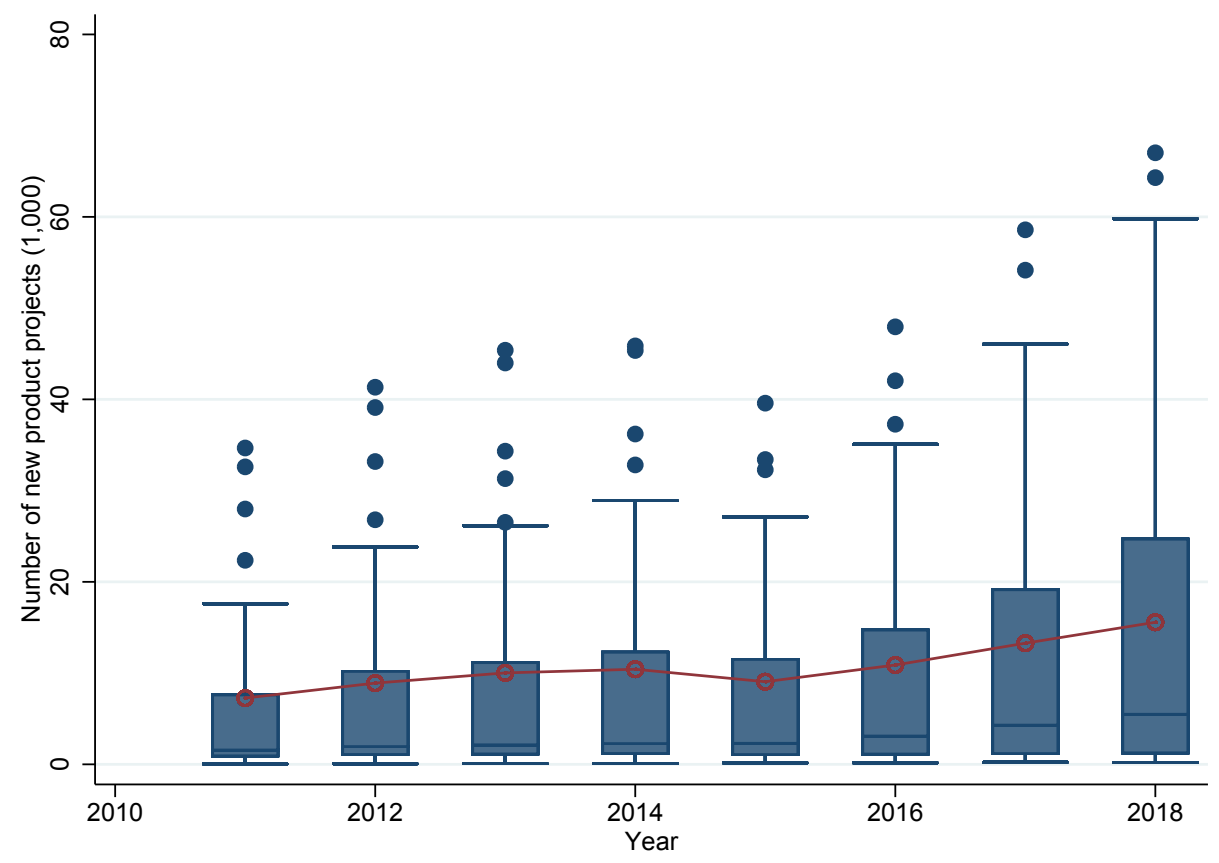

Figure 6.4 Distributions of the number of new-product projects, 2011-2018 Source: NBS (2021). 
In summary, innovation activities are on a rising trajectory in China, whether measured in terms of inputs ( $\& \& D$ expenditure and researchers) or outputs (patents and product, process, organisational and marketing innovation). With these rising trends, it is important to investigate how they affect the Chinese economy. Therefore, in the next two sections, I examine the impact of innovation on national GDP and on industrial outputs at the industry level.

\section{Innovation and GDP}

To investigate the impact of innovation on economic growth in China, I utilise the aggregate production function framework; and, since the data are a time series from 1989 to 2019, an autoregressive distributed lag model is used in the estimations, as in Equation 6.1.

\section{Equation 6.1}

$$
\begin{aligned}
\Delta \ln Y_{t}=\alpha_{0}+ & \sum_{p=1}^{P} \alpha_{1}^{p} \ln Y_{t-p}+\alpha_{2} \ln I_{t}+\alpha_{3} \ln K_{t}+\alpha_{4} \ln L_{t} \\
& +\sum_{q=-Q}^{Q} \alpha_{5}^{q} \Delta \ln I_{t-p}+\sum_{q=-Q}^{Q} \alpha_{6}^{q} \Delta \ln L_{t-p} \\
& +\sum_{q=-Q}^{Q} \alpha_{7}^{q} \Delta \ln K_{t-p}+\varepsilon_{t}
\end{aligned}
$$

In Equation 6.1, $Y, I, L$ and $K$ represent GDP, innovation, labour and capital, respectively; $\Delta$ is the difference operator; $\varepsilon$ is the error term; and $P$ and $Q$ are the lag lengths. In the estimations, due to the small sample size, I set $P=1$ in most estimations. If the error terms exhibit autocorrelation in an estimation, I instead set $P=2$. The lag length, $\mathrm{Q}$, is also set to 1 in the estimations, and sometimes no lead is used. Conceptually, it is possible that some right-hand-side variables are endogenous. For example, on the one hand, innovation promotes economic growth, while on the other, higher economic growth is likely to lead to higher innovation as economic growth facilitates investment in innovation. The lags and leads of differenced $\ln L, \ln K$ and $\ln I$ are intended to absorb such possible correlations with the error term. Innovation is captured by four dimensions in the regressionsnamely, the number of full-time-equivalent $R \& D$ researchers, $R \& D$ expenditure (as a share of GDP), the number of patent applications by residents and the number of patent applications by non-residents. Note that, in the ARDL model, the longrun impact of innovation can be measured by $\alpha_{2} /\left(-\sum_{p=1}^{P} \alpha_{1}^{p}\right)$. 
The data on GDP are sourced from the World Development Indicators (WDI) (World Bank 2021), which are in constant 2010 US dollars. The labour force (unit: 10,000) acts as a proxy for labour, sourced from the National Bureau of Statistics of China (NBS 2021). Data on capital are the gross fixed capital formation (percentage of gross national income, or GNI), calculated as the ratio of total investment in fixed assets against GNI, which are also sourced from the NBS. For innovation, data on $\mathrm{R} \& \mathrm{D}$ expenditure (percentage of GDP) and the number of full-time-equivalent R\&D researchers (unit: 10,000 persons per year) are obtained from the NBS, while data on patent applications by residents and non-residents are sourced from the WDI. I first test the stationarity of the time series $(\ln Y, \ln I, \ln L$ and $\operatorname{Ln} K)$, and Table 6.1 reports the results. Except $\ln L$, the other series are all I(1) and $\ln L$ is I(0). Therefore, an ARDL model is appropriate in this case.

Table 6.2 reports the estimation results, for which labour and capital are not included. In the estimations, a number of diagnostic tests were conducted, which verify the validity of the estimations. For example, for the regression where innovation is measured as the number of full-time-equivalent $\mathrm{R} \& \mathrm{D}$ researchers (column [1] of Table 6.2), the Ramsey regression equation specification error test (RESET test) finds a test statistic of 1.09 ( $p$-value of 0.3829), which fails to reject the null hypothesis that the model has no omitted variables. The Breusch-Pagan test for heteroskedasticity obtains a test statistic of 8.76 ( $p$-value of 0.119 ), suggesting no presence of heteroskedasticity. The Dickey-Fuller test of the predicted residuals obtains a test statistic of -3.093 (with drift, and $p$-value of 0.0027), confirming that the residuals are stationary $(\mathrm{I}(0))$. Durbin's alternative test for autocorrelation finds a test statistic of 4.593 with $p$-value of 0.0321 , which fails to reject the null hypothesis of no first-order autocorrelation at the 1 per cent level. The BreuschGodfrey Lagrange multiplier (LM) test for autocorrelation also fails to reject the null of no serial correlation from orders one to five at the 1 per cent level.

The LM test for autoregressive conditional heteroskedasticity (ARCH) fails to reject the null of no ARCH effects from orders one to five at the 1 per cent level. I also plot the cumulative sums of the recursive residuals and their squares from the regression, which stay within their 95 per cent confidence bands, confirming the stability of the regression (graph not reported to save space). For the other regressions, including those where I include $\ln L$ and $\ln K$ in Table 6.4, the same diagnostic tests are applied and, when applicable, adjustments are made to accommodate the findings of these tests. For example, in column [3] of Table 6.2, the standard errors are robust as the Breusch-Pagan test rejects the null of no heteroskedasticity at the 1 per cent level. These diagnostic tests are not reported, to save space, but are available on request. 
In the four regressions in Table 6.2, the estimated coefficients of innovation are statistically nonsignificant at the 5 per cent level for regressions [1], [3] and [4]. In contrast, the innovation coefficient is estimated to be positive and significant at the 5 per cent level in regression [2]. The nonsignificant estimates appear to suggest that innovation measured in terms of the number of $R \& D$ researchers and patent applications of residents and non-residents plays a less important role in economic growth in the short term. In the four regressions, some of the estimated coefficients of the lags of differenced innovation are statistically significant, suggesting a time lag for innovation. The significant estimate of the coefficient of innovation, measured in terms of R\&D expenditure as a share of GDP, is likely to capture the short-term growth effect for non-innovation-related spending.

In the long run, the situations are different. In all four regressions, the estimated coefficients of innovation are positive and statistically significant at the 5 per cent level, suggesting that innovation promotes economic growth in the long run. For $\mathrm{R} \& \mathrm{D}$ researchers, a 1 per cent increase in the number of full-time-equivalent $\mathrm{R} \& \mathrm{D}$ researchers results in a 0.69 per cent increase in aggregate output. The impact of $R \& D$ spending is even bigger, with an elasticity of 1.34 . It is interesting to compare the long-run coefficient of residents' patent applications with that of nonresidents. Despite both being significantly positive, the magnitude of the coefficient for non-residents' patent applications is higher, suggesting that non-residents' patent applications play a greater role in boosting economic growth.

In Table 6.2, the regressions do not control for the roles of labour and capital. I report the regression results that control for labour and capital inputs in Table 6.3. Capital, labour and innovation are highly correlated (pairwise correlation >0.86). With the small sample size, the multicollinearity issue is a concern. To address this, I first project labour on to the subspace spanned by an innovation measure and a vector of 1 to obtain a vector of labour measure that is orthogonal to the innovation measure and used in the regression. Second, I project capital to the subspace spanned by innovation, orthogonalised labour and a vector of 1 , from which I obtain an orthogonalised capital for the regressions.

Comparing the regression results of Table 6.3 with those of Table 6.2, unsurprisingly, we can observe differences in terms of the magnitude of the estimated coefficients. In particular, the short-run coefficient of innovation, measured in terms of $\mathrm{R} \& \mathrm{D}$ expenditure, now becomes statistically insignificant at the 5 per cent level. Nevertheless, the pattern in which innovation, measured in any one of the four dimensions, plays an insignificant role in economic growth in the short run while promoting economic growth in the long run continues to hold even after labour and capital are controlled in the regressions. Thus, the findings in Table 6.2 are robust. 
Table 6.1 Unit root tests

\begin{tabular}{|c|c|c|c|c|c|c|c|c|c|}
\hline \multirow[b]{3}{*}{ Variables } & \multicolumn{4}{|c|}{ Levels } & \multicolumn{4}{|c|}{ First difference } & \multirow[b]{3}{*}{ Results } \\
\hline & \multicolumn{2}{|c|}{ ADF } & \multicolumn{2}{|c|}{ PP } & \multicolumn{2}{|c|}{ ADF } & \multicolumn{2}{|c|}{ PP } & \\
\hline & Constant & $\begin{array}{l}\text { Constant } \\
+ \text { trend }\end{array}$ & Constant & $\begin{array}{c}\text { Constant } \\
+ \text { trend }\end{array}$ & Constant & $\begin{array}{c}\text { Constant } \\
\text { + Trend }\end{array}$ & Constant & $\begin{array}{c}\text { Constant } \\
\text { + trend }\end{array}$ & \\
\hline $\ln Y$ & -1.216 & -2.287 & -1.298 & -0.789 & -3.809 & -3.918 & -2.751 & -2.934 & $\mathrm{I}(1)$ \\
\hline $\operatorname{lnl}[1]$ & 0.603 & -1.771 & 0.421 & -1.845 & -3.924 & -3.891 & -3.938 & -3.914 & $\mathrm{I}(1)$ \\
\hline Inl [2] & -0.114 & -2.125 & -0.235 & -2.257 & -4.520 & -4.453 & -4.539 & -4.476 & $\mathrm{I}(1)$ \\
\hline Inl [3] & 1.348 & -2.457 & 1.052 & -2.425 & -4.660 & -4.547 & -4.670 & -4.571 & $\mathrm{I}(1)$ \\
\hline Inl [4] & -0.699 & -1.504 & -0.686 & -1.603 & -5.477 & -5.423 & -5.482 & -5.431 & $\mathrm{I}(1)$ \\
\hline $\ln L$ & -3.566 & -2.219 & -4.343 & -2.293 & -4.953 & -5.964 & -5.003 & -5.992 & $\mathrm{I}(0)$ \\
\hline InK & -0.976 & -1.287 & -1.062 & -1.782 & -2.955 & -2.896 & -2.942 & -2.880 & $\mathrm{I}(1)$ \\
\hline
\end{tabular}

Notes: The null hypothesis is that the series contains a unit root; for $\ln Y$, one year lag is used; [1] is the number of $R \& D$ researchers; [2] is $R \& D$ expenditure; [3] is patent applications by residents; and [4] is patent applications by non-residents.

Sources: Author's estimations using data from World Bank (2021); NBS (2021).

\section{Table 6.2 Regression results}

\begin{tabular}{|l|c|c|c|c|c|c|c|c|}
\hline & \multicolumn{2}{|c|}{ [1] } & \multicolumn{2}{c|}{ [2] } & \multicolumn{2}{c|}{ [3] [4] } \\
\hline & Coef. & S.E. & Coef. & S.E. & Coef. & S.E. & Coef. & S.E. \\
\hline InYt-1 & $-0.05^{\star}$ & 0.03 & $0.58^{\star \star \star}$ & 0.09 & $0.68^{\star \star \star}$ & 0.19 & $0.88^{\star \star \star}$ & 0.18 \\
\hline InYt-2 & & & $-0.63^{\star \star \star}$ & 0.09 & $-0.71^{\star \star \star}$ & 0.20 & $-1.38^{\star \star \star}$ & 0.32 \\
\hline InYt-3 & & & & & & $0.49^{\star \star}$ & 0.18 \\
\hline Inlt & & & & & & 0.01 & 0.01 & 0.01 \\
\hline Constant & $1.38^{\star}$ & 0.69 & $1.41^{\star \star \star}$ & 0.30 & 0.84 & 0.64 & 0.41 & 0.38 \\
\hline & & & & \multicolumn{7}{|c|}{ Long-run coefficient } & & \\
\hline Inl & $0.69^{\star \star \star}$ & 0.22 & $1.34^{\star \star \star}$ & 0.10 & $0.37^{\star \star \star}$ & 0.09 & $0.63^{\star \star \star}$ & 0.19 \\
\hline N & 25.00 & & 28.00 & & 31.00 & & 30.00 & \\
\hline F & 6.44 & & 18.25 & & 7.29 & & 5.01 & \\
\hline Adj. R2 & 0.53 & & 0.79 & & 0.51 & & 0.49 & \\
\hline
\end{tabular}

${ }^{* * *}$ significant at the 1 per cent level

** significant at the 5 per cent level

* significant at the 10 per cent level

Notes: In [1], innovation is measured as the number of full-time-equivalent R\&D researchers; in [2], innovation is R\&D expenditure as a share of GDP; in [3], innovation is the number of residents' patent applications, and the standard errors are robust; in [4], innovation is the number of non-residents' patent applications. The coefficients of lags and leads of differenced terms are not reported, to save space.

Sources: Author's estimations using data from World Bank (2021); NBS (2021). 
Table 6.3 Regression results with capital and labour

\begin{tabular}{|c|c|c|c|c|c|c|c|c|}
\hline & \multicolumn{2}{|c|}{ [1] } & \multicolumn{2}{|c|}{ [2] } & \multicolumn{2}{|c|}{ [3] } & \multicolumn{2}{|c|}{ [4] } \\
\hline & Coef. & S.E. & Coef. & S.E. & Coef. & S.E. & Coef. & S.E. \\
\hline $\operatorname{lnYt-1}$ & 0.05 & 0.08 & $0.49^{\star \star \star}$ & 0.15 & $-0.11^{\star \star}$ & 0.04 & $-0.17^{\star \star \star}$ & 0.05 \\
\hline InYt-2 & & & $-0.57^{\star \star \star}$ & 0.13 & & & & \\
\hline Inlt & -0.08 & 0.08 & 0.12 & 0.09 & $0.04^{\star \star}$ & 0.02 & $0.10^{\star \star \star}$ & 0.04 \\
\hline $\ln L t$ & -0.39 & 0.49 & 0.00 & 0.43 & $0.20^{\star \star}$ & 0.09 & $0.28^{\star \star \star}$ & 0.09 \\
\hline InKt & $0.20^{\star \star *}$ & 0.06 & 0.02 & 0.05 & 0.07 & 0.07 & $0.17^{\star \star}$ & 0.06 \\
\hline \multirow[t]{2}{*}{ Constant } & -0.95 & 1.86 & 2.43 & 1.51 & $2.80^{\star \star \star}$ & 0.98 & $3.84^{\star \star \star}$ & 1.16 \\
\hline & \multicolumn{8}{|c|}{ Long-run coefficients } \\
\hline Inl & $1.58^{*}$ & 0.88 & $1.45^{\star \star \star}$ & 0.18 & $0.40^{\star \star \star}$ & 0.03 & $0.62^{\star \star \star}$ & 0.01 \\
\hline $\operatorname{lnL}$ & $7.55^{\star \star}$ & 3.41 & 1.62 & 4.46 & $1.86^{\star \star \star}$ & 0.49 & $1.62^{\star \star \star}$ & 0.23 \\
\hline InK & -3.48 & 6.65 & 0.39 & 0.40 & 0.85 & 0.78 & $0.99^{\star \star \star}$ & 0.08 \\
\hline $\mathrm{N}$ & 25.00 & & 28.00 & & 32.00 & & 32.00 & \\
\hline $\mathrm{F}$ & 8.06 & & 10.22 & & 4.7 & & 5.62 & \\
\hline Adj. R2 & 0.75 & & 0.79 & & 0.54 & & 0.60 & \\
\hline
\end{tabular}

*** significant at the 1 per cent level

** significant at the 5 per cent level

* significant at the 10 per cent level

Notes: In [1], innovation is measured as the number of full-time-equivalent R\&D researchers; in [2], innovation is R\&D expenditure as a share of GDP; in [3], innovation is the number of residents' patent applications; in [4], innovation is the number of non-residents' patent applications. The coefficients of lags and leads of differenced terms are not reported, to save space.

Sources: Author's estimations using data from World Bank (2021); NBS (2021).

\section{Industry analysis}

Similar to the national-level analysis, the industry-level analysis also starts with the aggregate production function framework, where the industry output is a function of capital, labour and a measure of innovation. Unlike the ARDL model in section four, since we are using balanced panel data, here we utilise the fixed-effect estimator in the regressions. The empirical model is Equation 6.2.

\section{Equation 6.2}

$\ln Y_{i t}=\beta_{0}+\beta_{1} \ln I_{i t}+\beta_{2} \ln K_{i t-2}+\beta_{3} \ln K_{i t-2}+\zeta_{i}+\epsilon_{i t}$

In Equation 6.2, $Y, I, K$ and $L$ are the industry output (revenue), a measure of innovation, capital and labour, respectively; $\varepsilon$ is the error term; $\zeta$ is the unobserved industry fixed effect that can be correlated with the inputs $(K, L$ and $I)$; and the subscripts $i$ and $t$ denote industry and year, respectively. The inputs in the righthand side of the equation can be endogenous. So, for $K$ and $L$, I use the two-year 
lag to alleviate the possible endogeneity of capital and labour. For innovation, I utilise two years lead of the level and difference of the innovation measure as the excluded instruments. ${ }^{2}$

The industry panel data are sourced from the NBS and the China Industry Statistical Yearbook (NBS 2011-17) and cover 28 two-digit industries over six years (2012-18). The two-digit industries are aggregates of enterprises above a designated size, and as such do not include all firms in the relevant industry. The industry output (revenue, unit: RMB100 million) is deflated using the ex-factory price index of industrial producers $(1985=100)$. Capital is proxied by the total assets in the industry (unit: RMB100 million), which is deflated by using the fixed-asset investment price index $(1990=100)$. Labour is measured as the average number of workers in each industry (unit: 1,000 persons), data for which are sourced from the China Industry Statistical Yearbook (NBS 2011-17).

I use four indicators to measure innovation: the number of new-product projects, full-time-equivalent $R \& D$ researchers, $R \& D$ projects and valid invention patents. These four indicators capture both the input and the output perspectives of innovation activities, and Table 6.4 presents the summary statistics of these variables. We can observe substantial variations for all variables, which allow for identification of the impact of innovation. For example, on average, industries have revenues of almost RMB110 billion with a standard deviation of more than RMB100 billion. The revenue for the highest industry is more than 490 times that of the lowest industry.

Table 6.5 presents the regression results, where the first two columns (FE [1] and FE [2]) are fixed-effect estimations assuming exogeneity of explanatory variables and the second two columns (IV FE [1] and IV FE [2]) account for the potential endogeneity of innovation. In the IV FE estimations, I check the relevance and validity of excluded instruments by the under-identification (the KleibergenPaap rk LM test), weak identification (the Kleibergen-Paap rk Wald F test) and over-identification tests (the Hansen J test), and in all regressions the excluded instruments are relevant and valid. For example, in the regression with capital, labour and the number of new-product projects, the Kleibergen-Paap rk LM test statistic is 40.58 ( $p$-value $<0.01$ ), rejecting the null hypothesis that excluded instruments are irrelevant. The Kleibergen-Paap rk Wald F test statistic is 102.85-higher than the critical value of the Stock-Yogo weak identification test (10 per cent maximal IV size: 19.93). The Hansen J statistic is 0.735 ( $p$-value of 0.3914 ), suggesting the excluded instruments are valid.

2 Except for the regression with the number of full-time-equivalent R\&D researchers, capital and labour (the right column of panel [2] in Table 6.5), where the excluded instruments are four years lead of innovation and three years lead of differenced innovation as the two years lead instruments do not pass the Hansen J test. 
In all regressions, the estimated coefficients of innovation, measured for any of the four indicators, are positive and statistically significant at the 1 per cent level. The significantly positive estimates suggest that innovation promotes industrial development in China. A 1 per cent increase in the number of new-product projects and the number of valid invention patents results in an approximately 0.8 per cent increase in the industrial output. Similarly, a 1 per cent increase in the number of full-time-equivalent $R \& D$ researchers and the number of $R \& D$ projects leads to an approximately 1 per cent increase in industrial output. Note that, despite the fact the magnitudes of the estimated coefficients of innovation exhibit some variation, they are generally consistent with each other in the sense that one estimate is not too far away from the others.

Therefore, as with the findings from national-level analysis, the industry-level analysis also confirms the growth effect of innovation, which is robust to different measures of innovation activity. Note that the industry panel data only cover seven years, and our regressions here estimate the long-run effect of innovation, rather than examining the short-run dynamics.

In Table 6.5, due to issues of data availability, process, marketing and organisational innovation are not examined. For process innovation, the available data cover 21 two-digit industries in the manufacturing sector over three years (2016-18). For marketing and organisational innovation, the data are cross-sectional, covering 28 two-digit industries in 2018. Table 6.6 reports the estimation results for process innovation, where the excluded instruments are its one-year lead of level and one-year lag of differenced process innovation. The statistical tests suggest these instruments are relevant, valid and not weak. Table 6.7 reports the regression results for marketing and organisational innovations, where I assume exogeneity of innovations, and therefore the estimated coefficients measure association, rather than causality. In both tables, the process, marketing and organisational innovations are measured as the shares of the number of innovating firms in the two-digit industries (percentage).

In Table 6.6, the estimated coefficient of process innovation is 0.01 , which is statistically significant at the 1 per cent level. A 1 per cent increase in the share of firms that conduct process innovation results in a 0.01 per cent increase in industry output. In Table 6.7, the coefficients of marketing and organisational innovation are estimated to be 0.06 and 0.07 , respectively, both of which are statistically significant at the 1 per cent level. The estimates suggest that both marketing and organisational innovations are positively associated with industry output. Therefore, with this smaller sample, we continue to observe significant growth effects from innovation. 
Table 6.4 Summary statistics

\begin{tabular}{|l|c|c|c|c|}
\hline \multicolumn{1}{|c|}{ Variable } & Mean & Std dev. & Min. & Max. \\
\hline Yt & $1,093.7110$ & $1,000.8160$ & 8.58 & $4,222.00$ \\
\hline Kt-2 & $25,645.9900$ & $24,167.5000$ & $1,882.30$ & $134,531.40$ \\
\hline Lt-2 & 244.1529 & 212.3263 & 13.13 & 909.26 \\
\hline npp & $11,163.2600$ & $15,076.9000$ & 65.00 & $67,027.00$ \\
\hline ferdr & $73,200.9100$ & $99,088.3900$ & 566.80 & $552,618.00$ \\
\hline rdp & $10,263.7800$ & $12,696.4100$ & 85.00 & $52,317.00$ \\
\hline nip & $19,176.2400$ & $40,928.2400$ & 49.00 & $300,369.00$ \\
\hline
\end{tabular}

Notes: $\mathrm{N}=196 ; \mathrm{Y}_{\mathrm{t}}=$ unit = RMB100 billion (current price); $\mathrm{K}_{\mathrm{t}-2}=$ unit = RMB100 billion (current price); $L_{t-2}=$ unit = 10,000; $n p p=$ number of new-product projects; ferdr = number of full-time-equivalent R\&D researchers; $r d p=$ number of R\&D projects; nip = number of valid invention patents.

Source: NBS (2021).

Table 6.5 Industry estimation results

\begin{tabular}{|c|c|c|c|c|c|c|c|c|}
\hline & \multicolumn{2}{|c|}{ FE [1] } & \multicolumn{2}{|c|}{ FE [2] } & \multicolumn{2}{|c|}{ IV FE [1] } & \multicolumn{2}{|c|}{ IV FE [2] } \\
\hline & Coef. & S.E. & Coef. & S.E. & Coef. & S.E. & Coef. & S.E. \\
\hline & \multicolumn{8}{|c|}{ [1] Innovation: Number of new-product projects } \\
\hline$|n|_{t}$ & $0.68^{* *+}$ & 0.04 & $0.53^{* * *}$ & 0.06 & $0.76^{* * *}$ & 0.07 & $0.80^{* * *}$ & 0.10 \\
\hline $\ln K_{t-2}$ & & & -0.08 & 0.13 & & & 0.03 & 0.12 \\
\hline $\ln L_{t-2}$ & & & $0.35^{\text {t*t }}$ & 0.11 & & & -0.22 & 0.14 \\
\hline $\mathrm{N}$ & 196.00 & & 196.00 & & 182.00 & & 182.00 & \\
\hline $\mathrm{F}$ & 341.92 & & 144.40 & & 102.09 & & 105.94 & \\
\hline Centred $\mathrm{R}^{2}$ & 0.73 & & 0.74 & & 0.63 & & 0.62 & \\
\hline K-P rk LM & & & & & 26.81 & & 40.58 & \\
\hline K-P rk Wald F & & & & & 52.23 & & 102.85 & \\
\hline \multirow[t]{2}{*}{ Hansen J } & & & & & 0.02 & & 0.74 & \\
\hline & \multicolumn{8}{|c|}{ [2] Innovation: Number of full-time-equivalent R\&D researchers } \\
\hline$\left.\operatorname{ln|}\right|_{t}$ & $0.77^{*+*}$ & 0.04 & $0.76^{\text {tat }}$ & 0.09 & $1.10^{*+*}$ & 0.12 & $0.34^{*+*}$ & 0.13 \\
\hline $\ln K_{t-2}$ & & & $-0.23^{*}$ & 0.13 & & & $0.38^{+*+t}$ & 0.09 \\
\hline $\ln \mathrm{L}_{\mathrm{t}-2}$ & & & 0.21 & 0.13 & & & 0.19 & 0.17 \\
\hline $\mathrm{N}$ & 196.00 & & 196.00 & & 182.00 & & 168.00 & \\
\hline $\mathrm{F}$ & 438.03 & & 154.28 & & 88.01 & & 557.19 & \\
\hline Centred $\mathrm{R}^{2}$ & 0.73 & & 0.74 & & 0.38 & & 0.80 & \\
\hline K-P rk LM & & & & & 27.51 & & 18.91 & \\
\hline K-P rk Wald F & & & & & 35.91 & & 14.61 & \\
\hline Hansen J & & & & & 0.53 & & 6.06 & \\
\hline
\end{tabular}




\begin{tabular}{|c|c|c|c|c|c|c|c|c|}
\hline & \multicolumn{2}{|c|}{ FE [1] } & \multicolumn{2}{|c|}{ FE [2] } & \multicolumn{2}{|c|}{ IV FE [1] } & \multicolumn{2}{|c|}{ IV FE [2] } \\
\hline & Coef. & S.E. & Coef. & S.E. & Coef. & S.E. & Coef. & S.E. \\
\hline & \multicolumn{8}{|c|}{ [3] Innovation: Number of R\&D projects } \\
\hline$\left.\ln \right|_{t}$ & $0.78^{+\ldots+*}$ & 0.04 & $0.66^{* * *}$ & 0.07 & $1.07^{*+*}$ & 0.12 & $1.17^{*+*}$ & 0.15 \\
\hline $\operatorname{lnK}_{\mathrm{t}-2}$ & & & -0.22 & 0.13 & & & $-0.25^{* \prime}$ & 0.12 \\
\hline $\operatorname{lnL} \mathrm{t}_{\mathrm{t}-2}$ & & & $0.37^{*+*+1}$ & 0.11 & & & $-0.31^{*}$ & 0.17 \\
\hline $\mathrm{N}$ & 196.00 & & 196.00 & & 182.00 & & 182.00 & \\
\hline $\mathrm{F}$ & 440.66 & & 173.36 & & 81.15 & & 86.47 & \\
\hline Centred $\mathrm{R}^{2}$ & 0.72 & & 0.74 & & 0.43 & & 0.51 & \\
\hline K-P rk LM & & & & & 27.60 & & 41.24 & \\
\hline K-P rk Wald F & & & & & 37.57 & & 81.17 & \\
\hline \multirow[t]{2}{*}{ Hansen J } & & & & & 0.05 & & 9.80 & \\
\hline & \multicolumn{8}{|c|}{ [4] Innovation: Number of valid invention patents } \\
\hline$\left.\ln \right|_{t}$ & $0.64^{* *}$ & 0.03 & $0.44^{* \ldots+}$ & 0.04 & $0.79+$ & 0.08 & $0.98^{* * *}$ & 0.16 \\
\hline $\operatorname{lnK}_{\mathrm{t}-2}$ & & & $-0.31^{*}$ & 0.15 & & & $-0.48^{* *+}$ & 0.18 \\
\hline $\operatorname{lnL} L_{t-2}$ & & & $0.66^{*+*}$ & 0.11 & & & 0.00 & 0.18 \\
\hline $\mathrm{N}$ & 196.00 & & 196.00 & & 182.00 & & 182.00 & \\
\hline $\mathrm{F}$ & 333.29 & & 149.03 & & 93.05 & & 74.56 & \\
\hline Centred $\mathrm{R}^{2}$ & 0.65 & & 0.71 & & 0.45 & & 0.35 & \\
\hline K-P rk LM & & & & & 29.92 & & 37.86 & \\
\hline K-P rk Wald F & & & & & 63.77 & & 45.74 & \\
\hline Hansen J & & & & & 3.57 & & 0.67 & \\
\hline
\end{tabular}

${ }^{* * *}$ significant at the 1 per cent level

* significant at the 5 per cent level

* significant at the 10 per cent level

Notes: Standard errors are robust to heteroskedasticity and autocorrelation; K-P rk LM = KleibergenPaap rk LM test statistic; K-P rk Wald F = Kleibergen-Paap rk Wald F test statistic; year dummies are dropped in the regression due to multicollinearity.

Source: Author's estimations using data from NBS (2021).

Table 6.6 Industry estimation results: Process innovation

\begin{tabular}{|l|c|c|c|c|c|c|c|c|}
\hline & \multicolumn{4}{|c|}{ FE } & \multicolumn{5}{c|}{ IV FE } \\
\hline & Coef. & S.E. & Coef. & S.E. & Coef. & S.E. & Coef. & S.E. \\
\hline$\left.\ln \right|_{t}$ & -0.0020 & 0.02 & -0.003 & 0.01 & $0.08^{\star \star \star}$ & 0.01 & $0.01^{\star \star \star}$ & 0.00 \\
\hline $\ln K_{t-2}$ & & & 0.060 & 0.31 & & & $0.71^{\star \star \star}$ & 0.04 \\
\hline $\operatorname{lnL}_{t-2}$ & & & $0.720^{\star \star \star}$ & 0.23 & & & $0.27^{\star \star \star}$ & 0.05 \\
\hline $\mathrm{N}$ & 63.0000 & & 63.000 & & 54.00 & & 54.00 & \\
\hline $\mathrm{F}$ & 0.0100 & & 33.730 & & 29.01 & & 54.00 & \\
\hline Centred $\mathrm{R}^{2}$ & 0.0003 & & 0.440 & & -0.27 & & 0.97 & \\
\hline
\end{tabular}




\begin{tabular}{|l|l|l|l|l|l|l|l|l|}
\hline & \multicolumn{3}{|c|}{ FE } & \multicolumn{4}{c|}{ IV FE } \\
\hline & Coef. & S.E. & Coef. & S.E. & Coef. & S.E. & Coef. & S.E. \\
\hline K-P rk LM & & & & & 17.02 & & 17.63 & \\
\hline K-P rk Wald F & & & & & 73.29 & & 78.84 & \\
\hline Hansen J & & & & & 5.04 & & 1.63 & \\
\hline
\end{tabular}

*** significant at the 1 per cent level

* significant at the 5 per cent level

* significant at the 10 per cent level

Notes: Standard errors are robust to heteroskedasticity and autocorrelation; K-P rk LM = KleibergenPaap rk LM test statistic; K-P rk Wald F = Kleibergen-Paap rk Wald F test statistic; year dummies are dropped in the regression due to multicollinearity.

Source: Author's estimations using data from NBS (2021).

Table 6.7 Industry estimation results: Marketing and organisational innovation

\begin{tabular}{|l|c|c|c|c|c|c|c|c|}
\hline & \multicolumn{4}{|c|}{ [1] Marketing } & \multicolumn{4}{c|}{ [2] Organisational } \\
\hline & Coef. & S.E. & Coef. & S.E. & Coef. & S.E. & Coef. & S.E. \\
\hline $\operatorname{In}_{t}$ & $0.09^{\star \star \star}$ & 0.02 & $0.06^{\star \star *}$ & 0.01 & $0.11^{\star \star \star}$ & 0.02 & $0.07^{\star \star \star}$ & 0.02 \\
\hline $\operatorname{lnK}_{t-2}$ & & & -0.02 & 0.34 & & & -0.33 & 0.40 \\
\hline $\operatorname{lnL}_{t-2}$ & & & $0.78^{\star \star \star}$ & 0.22 & & & $1.08^{\star \star \star}$ & 0.28 \\
\hline Constant & $2.88^{\star \star \star}$ & 0.48 & -0.26 & 1.91 & $2.12^{\star \star \star}$ & 0.69 & 0.51 & 2.00 \\
\hline $\mathrm{N}$ & 28.00 & & 28.00 & & 28.00 & & 28.00 & \\
\hline F & 27.26 & & 36.27 & & 23.51 & & 34.18 & \\
\hline Centred $R^{2}$ & 0.50 & & 0.75 & & 0.38 & & 0.72 & \\
\hline
\end{tabular}

${ }^{* * *}$ significant at the 1 per cent level

** significant at the 5 per cent level

* significant at the 10 per cent level

Note: Standard errors are robust to heteroskedasticity.

Source: Author's estimations using data from NBS (2021).

\section{Concluding remarks}

This chapter aims to provide an update of aggregate innovation activity in China. In light of the increasingly binding resource constraints-for example, depletion of cheap labour released from the agricultural sector-innovation is likely to play an important role in China's future economic development. Therefore, it is important to examine innovation in China to gain a better understanding of the country's future growth trajectory. I focus on the growth effects of innovation in China from several dimensions-namely, the input perspective of $R \& D$ expenditure and the number of $\mathrm{R} \& \mathrm{D}$ researchers, as well as the output perspective of patents and product, process, organisational and marketing innovation. 
The main message of this chapter is threefold: first, innovation in China is on a growth trajectory, with this growth showing little evidence of slowing; second, innovation appears to promote economic growth in the long run at both the national and the industry levels; and third, there is a lack of a short-run growth effect from innovation at the national level. With four decades of economic growth, China is paying more and more attention to innovation, which is likely to become a new source of future economic growth. This study utilises aggregate national and industry data. Future studies, on the other hand, will be able to explore disaggregated data at the firm or project level to provide a picture of innovation in China from an alternative angle.

\section{References}

Acemoglu, D., Bimpikis, K. and Ozdaglar, A. (2011), Experimentation, patents, and innovation, American Economic Journal: Microeconomics 3(1): 37-77. doi.org/10.1257/ mic.3.1.37.

Aldieri, L. (2011), Technological and geographical proximity effects on knowledge spillovers: Evidence from the US patent citations, Economics of Innovation and New Technology 20(6): 597-607. doi.org/10.1080/10438599.2011.554632.

Anwar, S. and Sun, S. (2013), Foreign entry and firm R\&D: Evidence from Chinese manufacturing industries, R\&D Management 43(4): 303-17. doi.org/10.1111/radm. 12009.

Bai, J. (2013), On regional innovation efficiency: Evidence from panel data of China's different provinces, Regional Studies 47(5): 773-88. doi.org/10.1080/00343404.2011. 591784.

Belderbos, R., Leten, B. and Suzuki, S. (2013), How global is R\&D? Firm-level determinants of home-country bias in R\&D, Journal of International Business Studies 44(8): 765-86. doi.org/10.1057/jibs.2013.33.

Boeing, P. and Mueller, E. (2019), Measuring China's patent quality: Development and validation of ISR indices, China Economic Review 57: 101331. doi.org/10.1016/j.chieco. 2019.101331.

Buesa, M., Heijs, J. and Baumert, T. (2010), The determinants of regional innovation in Europe: A combined factorial and regression knowledge production function approach, Research Policy 39(6): 722-35. doi.org/10.1016/j.respol.2010.02.016.

Cai, F. (2010), Demographic transition, demographic dividend, and Lewis turning point in China, China Economic Journal 3(2): 107-19. doi.org/10.1080/17538963.2010.51 1899. 
Chan, H.P. (2010), The determinants of international patenting for nine agricultural biotechnology firms, The Journal of Industrial Economics 58(2): 247-78. doi.org/10.1111/ j.1467-6451.2010.00420.x.

Chen, K. and Guan, J. (2010), Measuring the efficiency of China's regional innovation systems: Application of network data envelopment analysis (DEA), Regional Studies 46(3): 355-77. doi.org/10.1080/00343404.2010.497479.

Chun, H. and Mun, S.-B. (2012), Determinants of R\&D cooperation in small and medium-sized enterprises, Small Business Economics 39(2): 419-36. doi.org/10.1007/ s11187-010-9312-5.

Dai, X. and Cheng, L. (2018), The impact of product innovation on firm-level markup and productivity: Evidence from China, Applied Economics 50(42): 4570-81. doi.org/ 10.1080/00036846.2018.1458195.

Fan, P. (2014), Innovation in China, Journal of Economic Surveys 28(4): 725-45. doi.org/ $10.1111 /$ joes. 12083 .

Fan, P., Wan, G. and Lu, M. (2012), China's regional inequality in innovation capability, 1995-2006, China \& World Economy 20(3): 16-36. doi.org/10.1111/j.1749-124X. 2012.01285.x.

Figueroa, N. and Serrano, C.J. (2013), Patent trading flows of small and large firms, NBER Working Paper Series No. 18982, Cambridge, MA: National Bureau of Economic Research. doi.org/10.3386/w18982.

Fisch, C., Sandner, P. and Regner, L. (2017), The value of Chinese patents: An empirical investigation of citation lags, China Economic Review 45: 22-34. doi.org/10.1016/ j.chieco.2017.05.011.

Fischer, M.M., Fröhlich, J. and Gassler, H. (1994), An exploration into the determinants of patent activities: Some empirical evidence for Austria, Regional Studies 28(1): 1-12. doi.org/10.1080/00343409412331348026.

Fu, W., Diez, J.R. and Schiller, D. (2012), Regional innovation systems within a transitional context: Evolutionary comparison of the electronics industry in Shenzhen and Dongguan since the opening of China, Journal of Economic Surveys 26(3): 534-50. doi.org/10.1111/ j.1467-6419.2012.00721.x.

$\mathrm{Fu}, \mathrm{X}$. and Mu, R. (2014), Enhancing China's innovation performance: The policy choices, China \& World Economy 22(2): 42-60. doi.org/10.1111/j.1749-124X.2014.12061.x.

Garnaut, R. and Huang, Y. (2006), Continued rapid growth and the turning point in China's development, in R. Garnaut and L. Song (eds), The Turning Point in China's Economic Development, 12-34, Canberra: ANU Press. doi.org/10.22459/TPCED.08.2006.02.

Gedik, Y. (2012), Geographical localisation of knowledge spillovers by Australian patent citations, Economic Papers: A Journal of Applied Economics and Policy 31(2): 173-81. doi.org/10.1111/j.1759-3441.2012.00172.x. 
Gorodnichenko, Y. and Schnitzer, M. (2013), Financial constraints and innovation: Why poor countries don't catch up, Journal of the European Economic Association 11(5): 1115-52. doi.org/10.1111/jeea.12033.

Guo, D., Guo, Y. and Jiang, K. (2016), Government-subsidised R\&D and firm innovation: Evidence from China, Research Policy 45(6): 1129-44. doi.org/10.1016/j.respol. 2016.03.002.

Hammadou, H., Paty, S. and Savona, M. (2014), Strategic interactions in public R\&D across European countries: A spatial econometric analysis, Research Policy 43(7): 1217-26. doi.org/10.1016/j.respol.2014.01.011.

Hu, A.G.Z., Zhang, P. and Zhao, L. (2017), China as number one? Evidence from China's most recent patenting surge, Journal of Development Economics 124: 107-19. doi.org/ 10.1016/j.jdeveco.2016.09.004.

Huang, L., Liu, X. and Xu, L. (2010), Regional innovation and spillover effects of foreign direct investment in China: A threshold approach, Regional Studies 46(5): 583-96. doi.org/ 10.1080/00343404.2010.520694.

Jefferson, G.H., Bai, H., Guan, X. and Yu, X. (2006), R\&D performance in Chinese industry, Economics of Innovation and New Technology 15(4-5):345-66. doi.org/10.1080/ 10438590500512851.

Kastl, J., Martimort, D. and Piccolo, S. (2013), Delegation, ownership concentration and R\&D spending: Evidence from Italy, The Journal of Industrial Economics 61(1): 84-107. doi.org/10.1111/joie.12012.

Li, C. and Lu, J. (2018), R\&D, financing constraints and export green-sophistication in China, China Economic Review 47: 234-44. doi.org/10.1016/j.chieco.2017.08.007.

Liu, F.-C., Simon, D.F., Sun, Y.-T. and Cao, C. (2011), China's innovation policies: Evolution, institutional structure, and trajectory, Research Policy 40(7): 917-31. doi.org/ 10.1016/j.respol.2011.05.005.

López, A. (2008), Determinants of R\&D cooperation: Evidence from Spanish manufacturing firms, International Journal of Industrial Organization 26(1): 113-36. doi.org/10.1016/ j.ijindorg.2006.09.006.

Minami, R. and Ma, X. (2010), The Lewis turning point of Chinese economy: Comparison with Japanese experience, China Economic Journal 3(2): 163-79. doi.org/10.1080/175 38963.2010.511912.

National Bureau of Statistics of China (NBS) (2011-17), China Industry Statistical Yearbook, Beijing: China Statistics Press.

National Bureau of Statistics of China (NBS) (2021), Annual Data. Beijing: National Bureau of Statistics China. Available from: data.stats.gov.cn/easyquery.htm?cn=C01.

Nicholas, T.O.M. (2011), Did R\&D firms used to patent? Evidence from the first innovation surveys, The Journal of Economic History 71(4): 1032-59. 
Okamuro, H., Kato, M. and Honjo, Y. (2011), Determinants of R\&D cooperation in Japanese start-ups, Research Policy 40(5): 728-38. doi.org/10.1016/j.respol.2011.01.012.

Organisation for Economic Co-operation and Development (OECD) (2018), Oslo Manual 2018: Guidelines for collecting, reporting and using data on innovation, 4th edn, Paris: OECD. Available from: www.oecd.org/science/oslo-manual-2018-97892643 04604-en.htm.

Rafiq, S., Salim, R. and Smyth, R. (2016), The moderating role of firm age in the relationship between R\&D expenditure and financial performance: Evidence from Chinese and US mining firms, Economic Modelling 56: 122-32. doi.org/10.1016/j.econmod.2016. 04.003 .

Sun, S. and Anwar, S. (2019), R\&D activities and FDI in China's iron ore mining industry, Economic Analysis and Policy 62: 47-56. doi.org/10.1016/j.eap.2019.01.003.

Wang, Z., Yao, Z., Gu, G., Hu, F. and Dai, X. (2014), Multi-agent-based simulation on technology innovation-diffusion in China, Papers in Regional Science 93(2): 385-408.

World Bank (2021), World Development Indicators, Washington, DC: The World Bank Group. Available from: datatopics.worldbank.org/world-development-indicators/.

Wu, F., Wu, H. and Zhang, X. (2020), How does innovation activity affect firm export behavior? Evidence from China, Emerging Markets Finance and Trade 56(8): 1730-51. doi.org/10.1080/1540496X.2019.1694889.

Wu, X. (2012), The evolution of innovation policy in China: A brief introduction, Australian Economic Review 45(4): 463-66. doi.org/10.1111/j.1467-8462.2012.00706.x.

Zhang, D. and Xie, Y. (2020), Synergistic effects of in-house and contracted R\&D on export performance: Evidence from China, Applied Economics Letters 27(1): 9-13. doi.org/ 10.1080/13504851.2019.1605582.

Zhou, Y. (2014), Role of institutional quality in determining the R\&D investment of Chinese firms, China \& World Economy 22(4): 60-82. doi.org/10.1111/j.1749-124X. 2014.12075.x.

Zhou, Y. and Song, L. (2016), International trade and R\&D investment: Evidence from Chinese manufacturing firms, China \& World Economy 24(1): 63-84. doi.org/10.1111/ cwe.12144.

Zhu, C., Qiu, Z. and Liu, F. (2021), Does innovation stimulate employment? Evidence from China, Economic Modelling 94: 1007-17. doi.org/10.1016/j.econmod.2020.02.041. 
This text is taken from China's Challenges in Moving towards a High-income Economy, edited by Ligang Song and Yixiao Zhou, published 2021 by ANU Press, The Australian National University, Canberra, Australia.

doi.org/10.22459/CCMTHE.2021.06 